\title{
Plate Bearing Tests on Collapsible Soils Improved by Compaction
}

\author{
[Samir Ibrahim Shalaby]
}

\begin{abstract}
Collapsible soils are located in aired and semiarid regions around the world. Collapsible soils cause remarkable damage to overlying structures. To improve this soil type to allow building, it is necessary to create a compacted replacement top sand layer above this weak, compressible soil stratum to increase its bearing capacity, reduces displacement and changed soil behavior to brittle behavior. In this paper, the influence of using the same collapsing soil compacted at different compaction ratios as a replacement material with different thicknesses on collapse strains is studied using field plate load tests. The paper discusses the mechanisms of this system using a large-scale model footing for a case studies for a housing project in sixth of October city-Giza governorateEgypt. That site has a collapsible silty sand soil. Circular plates of $750-\mathrm{mm}$ diameter were employed in field tests. The loadsettlement were modeled under dry conditions of soil at natural water content of $4 \%$ and dry density of $14.5 \mathrm{~N} / \mathrm{m}^{3}$. Field plate load test results are presented and their capability in collapse characterization and evaluation are compared. Results of field plate load tests showed that the use of the same collapsing soil compacted at different compaction ratios as a replacement soil had a sensible influence in reducing collapse settlement and increase bearing capacity and get a better performance of shallow foundations on collapsible soils. Critical depth of compacted upper layer is $\mathbf{2 . 0}$ times footing width.
\end{abstract}

Keywords - collapsible soil, soil bearing capacity, plate load test, soil improvement, in situ tests , and soil replacement

\section{Introduction}

Soils that exhibit collapse typically have an open type of structure with many void spaces, which give rise to a metastable structure. The bulky grains are held together in a honey comb type of fabric by some type of bonding material or force at the points of contact.

Collapsible soils are not confined to arid regions and have been encountered in most parts of the world. In addition to naturally deposited collapsible soils, engineered compacted fills may exhibit collapsible strains if compaction specifications and quality control are not appropriate. Compacted fills may also develop a collapsible structure at low density.

Due to inundation, the negative pore-water pressure at the contact points decreases, giving rise to grain slippage and distortion. Larinov [7]; Dudley [5]; and Barden et al. [4] described the collapse phenomena in terms of the bonding materials present at the contact points.

Natural collapsible soil have relatively low density, less than $16 \mathrm{KN} / \mathrm{m}^{3}$ and low moisture content with loose structure.

Samir Ibrahiem Shalaby/ Associate Professor of Soil Mechanics \& Foundation Engineering

Faculty of Petroleum and Mining Engineering / Suez University Suez, Egypt
These soils posses relatively high apparent stiffness and strength at dry condition but these properties undergo substantial decrease upon wetting, leading to high volume changes and hence large deformations. Collapse may be triggered by water alone or by wetting and loads acting together.

Shallow footings, when built on these soils, have a low load-bearing capacity and undergo large settlements. Construction on collapsible soils often requires the utilization of ground improvement techniques. Reinforcement of the collapsible soils with granular fill layers is a soil improvement technique that is widely used. Collapsible soil behavior can be improved by totally or partially replacing the inadequate soils with layers of compacted granular fill .

In order to stabilize collapsible soils, there are some methods as; moistening and compaction using some additives such as cement or lime, ponding and infiltration wells, Kakoli,et al [6] and Sun, et al [10].

On the other hand, construction on collapsible soil in its natural state without special precautions may cause undesired results, Ayadat,T. and Hanna, A. [3].

Improving soil foundation can reduce the damages associated to soil collapse. A method for that consists in removing foundation soil, up to a specified depth, and then re-compacting it. This method can increase allowable bearing capacity and reduce soil deformations.

Plate load tests are the most common field tests for the evaluation of allowable pressures under foundations. The results of bearing plate tests are shown in the form of plate load-settlement curve, Fig 1, where the proportionality limit $\left(\mathrm{P}_{\mathrm{pr}}\right)$ on this curve is accepted as the safe bearing capacity for foundations. The advantages of plate load test include the minimization of soil sample disturbance, larger volume of soil being tested, and the test followed the actual field situation.

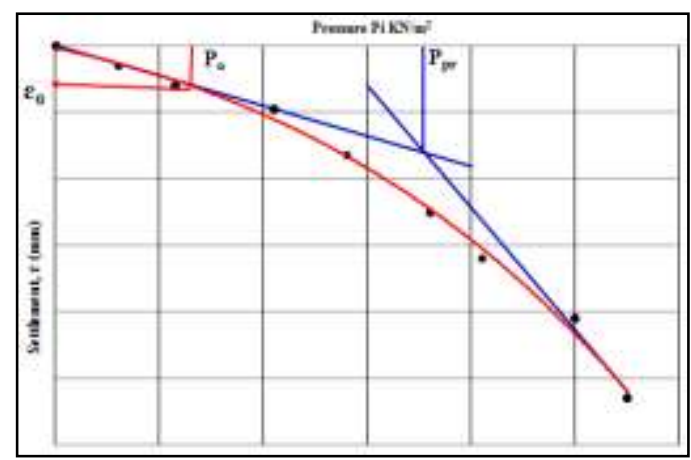

Figure 1. Diagram illustrating load intensity-bearing plate settlement curve.

Full-scale field test on collapsible soil with practical foundation size and load intensity, could provide a reliable 
information on load-settlement response and collapse potential, Adams et al.[1]; and Rollins et al. [9] .

This paper investigates the collapse potential of a newly developing district where the presence of collapsible soil layers was detected.

A series of field tests were conducted in this study to evaluate the effect of the use of the same natural collapsing soil without any treatment as a replacement soil on the bearing capacity and settlement. Thickness of replacement soil beneath foundation plate, and its percent compaction were studied to search, the best percentage of soil replacement compaction degree and the minimum thickness of soil replacement to reduced unfavorable collapse settlement and increase bearing capacity.

\section{Experimental work}

\section{A. Materials}

The collapsible soil used in this experimental program were collected from a trial test pits in a newly developing district in the northern extension of Sixth of October city Giza governorate - Egypt, where the presence of collapsible soil layers was detected near the ground surface by previous site investigations. Laboratory tests were performed on good quality samples trimmed from a block that was manually extracted at a depth of $2.0 \mathrm{~m}$ from ground surface. The tested engineering properties are listed in the following table.

\section{TABLE I. ENGINEERING PROPERTIES OF USED SOIL.}

\begin{tabular}{|c|c|}
\hline \multicolumn{2}{|l|}{ Collapsing soil } \\
\hline Specific gravity & 2.65 \\
\hline Liquid limit, WL (\%) & 31 \\
\hline Plasticity Index, IP $(\%)$ & 15 \\
\hline Natural water content $(\%)$ & 4.0 average \\
\hline Dry density $\left(\mathrm{KN} / \mathrm{m}^{3}\right)$ & 14.5 average \\
\hline Natural degree of saturation, $\mathrm{S}_{\mathrm{r}}$ & 0.233 \\
\hline Initial void ratio, $e_{0}$ & 0.875 \\
\hline Void ratio after saturation & 0.730 \\
\hline Clay fraction $(\%<2 \mu \mathrm{m})$ & 9 \\
\hline Silt fraction $(\%)$ & 31 \\
\hline Sand fraction $(\%)$ & 60 \\
\hline
\end{tabular}

Maximum dry unit weight and optimum moisture content were $18.7 \mathrm{KN} / \mathrm{m}^{3}$ and $10.2 \%$, respectively, considering Modified Proctor test.

\section{B. Field Load tests}

Field tests were performed in an area where thick layers (beyond $10 \mathrm{~m}$ in depth) of collapsible soils are found at a studied site in the northern extension of Sixth of October city. This soil has a low SPT values (Less than 10 blows).

Seven plate load tests (plate with 750-mm-diam, 25.4mm-thick,) at a depth of $2.0 \mathrm{~m}$ were performed considering the following soil conditions: After excavation, natural soil was flooded by water for 72 hour, the water level was allowed to remain at least $5 \mathrm{~cm}$ above the bottom of the hole, then left to be air dried for one week, the fine materials on the excavation base were collected and the soil surface was compacted.
Compacted treated soil was built over the collapsible soils in layers, $250 \mathrm{~mm}$ thick. Vibratory plate was used to reach the specific relative density of $85 \%-90 \%-95 \%$. Table 2 summarized the field test program .

TABLE II. FIELD TEST PROGRAM

\begin{tabular}{|c|c|c|c|c|}
\hline \multicolumn{2}{|c|}{$\begin{array}{c}\text { Thick. of replacement } \\
\text { layer (Hc/b) }\end{array}$} & \multicolumn{3}{|c|}{ \% Compaction of Replacement } \\
Soil \\
\hline 1.0 & 2.0 & 85 & 90 & 95 \\
\hline
\end{tabular}

\section{Experimental Procedure}

The top surface of the test area was leveled, and the footing was placed on a predefined alignment such that the loads from the hydraulic jack and the loading frame would be transferred concentrically to the footing.

The load was applied through a system compressing a hydraulic jack, a reaction beam connected with two adjacent anchor piles driven to a depth of $12 \mathrm{~ms}$. Load was measured using a calibrated load cell with capacity of $500 \mathrm{KN}$. Four dial gauges with divisions of 0.01 and $50 \mathrm{~mm}$ travel were used for settlement measurement. The gauges were fixed to a reference beam and supported on external rods. The experimental setup is shown in Fig. 2.

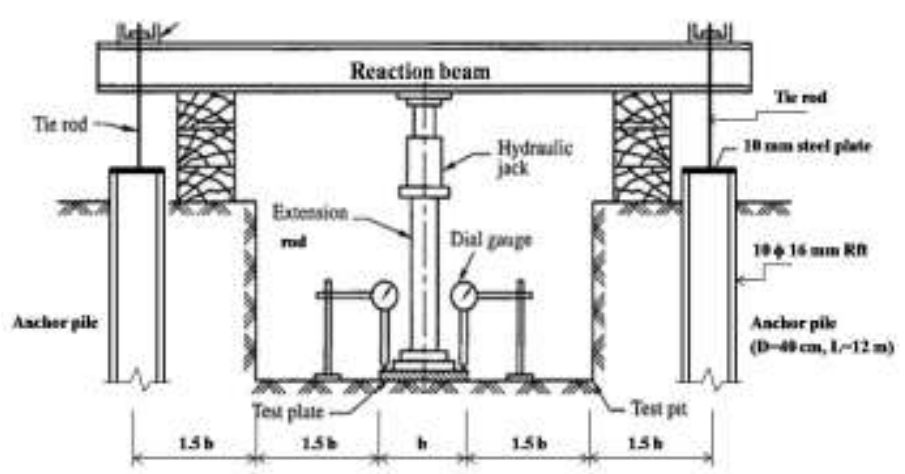

Figure 2. Schematic view of t experimental set-up, loading, reaction system.

The load was applied in cumulative increments such that the net pressure follows, in general, the following path: 0.0 , $50,100,150,200,300,350,400,450, \mathrm{KPa}$, etc. After the application of each load increment, the cumulative load was maintained until all settlements and collapse had creased. When the rate of deformation reaches less than 0.03 $\mathrm{mm} / \mathrm{min}$ over three consecutive minutes according to ASTM D 1196-93, [2].

The tests were continued until the applied vertical load was clearly reduced or a considerable settlement of the footing was obtained from a relatively small increase in vertical load. The stress-settlement curves were computed and plotted.

\section{Testing program}

To study the effect of the use of the same collapsing soil as a replacement soil on the stress-settlement behavior of plate footing resting on collapsible soil, a series of Field model footing tests under axial loads were performed.

The parameters studied are; thickness of replacement soil layer $\mathrm{Hc} / \mathrm{b}$ and $\%$ of compaction of soil replacement. 
In all tests the thickness of the replacement layer is represented in dimension less ratio $\mathrm{Hc} / \mathrm{b}=0.0,1.0$, and 2.0 where $(\mathrm{Hc})$ is the thickness of replacement layer and (b) is the footing diameter, as illustrated in Fig. 3 .

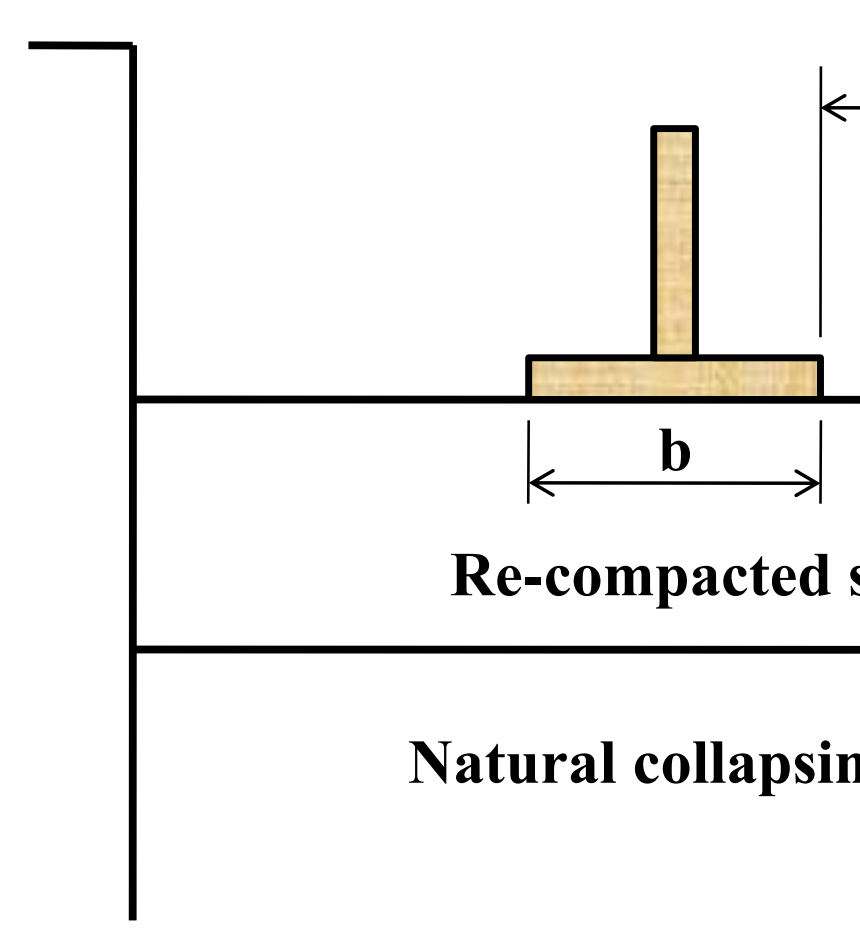

Figure 3. Typical dimensions of excavation used in field tests.

\section{Results and analysis}

The load intensity and settlement observation of the field plate load tests have been analyzed to study the effect of using the same collapsing soil as a replacement soil on the top of a collapsible soil on the settlement-strength of the collapsible bottom layer.

It can be inferred from the shape shown by the stresssettlement curves that there is no physical failure of the soilplate system.

In this study, the ultimate bearing capacity in any test is the intersection of two tangents, one draw to the initial straight line part of the settlement $\mathrm{x}$ load curve (elastic branch) and a second draw to the final steep branch, Leonards [8].

An initial reference test was performed for a footing resting directly on collapsible bed without soil replacement cushion as shown in Fig.4.

Plate Pressure (kPa) $\begin{array}{lllllllllll}0 & 50 & 100 & 150 & 200 & 250 & 300 & 350 & 400 & 450 & 500\end{array}$ $\mathrm{Hc} / \mathrm{b}=\mathbf{0 . 0}$ $1.5 \mathrm{~b}=$ कurt 20 寻 50 70 Figure 4. Stress-settlement cu rve of $75 \mathrm{~cm}$ plate on natural collapsing soil.

\section{A. Effect of thick hess of sand} rofplacement layer

Thickness of the replacement sand layer has a great effect on load-settlement relationship. The footing pressuresettlement relationships for model footing using top recompacted soil cushion are illustrated in Fig. 5. The loadsettlement curves were found to reach a peak value at larger $\mathrm{Hc} / \mathrm{b}$ ratio, where the mode of failure was general shear. From this figure it can be clearly seen that the ultimate bearing capacity increases with the increase of thickness of replacement soil layer, $(\mathrm{Hc} / \mathrm{b})$.

The results plotted on Fig. 5 show that the rate of settlement decreases with increase of both thickness and degree of compaction of the replacement layer, maximum decrease being observed with $\mathrm{Hc} / \mathrm{b}=2.0$ and $95 \%$ compaction degree.

Fig. 5. also illustrates the results of the tested plate load tests for various soil thicknesses for the three studied compaction ratios of the used replacement soil. The study of these results showed that for $\mathrm{Hc} / \mathrm{b}=1$ the ultimate load of the collapsing soil with top compacted soil layer increases by $145 \%, 160 \%$, and $190 \%$ respectively as compared to the origin collapsible soil. While for $\mathrm{Hc} / \mathrm{b}=2$ the increase was $160 \%, 200 \%$, and $220 \%$ respectively. Thus it is revealed that the inclusion of top soil replacement increases the stiffness of the soil which lead to an increase in bearing cabacity..

The meditation of the results shown in Fig. 6 elucidated that the degree of improvement on bearing capacity mainly related to thickness of replacement soil layer, wherever as the degree of compaction percent of the replacement soil reaches $95 \%$ and the thickness of replaced soil, $\mathrm{Hc} / \mathrm{b}=2$, the bearing capacity increases by about $220 \%$. This indicates that increasing thickness of replacement layer is capable of absorbing more strain energy prior to failure.

As it can be seen from Fig. 8, due to the increase of thickness of replacement layer, collapse settlement was reduces $62.5 \%$ (it decreases from $32 \mathrm{~mm}$ to $12 \mathrm{~mm}$.). 


\section{B. Effect of degree of replacement soil compaction}

The degree of replacement soil compaction has a great effect on load-settlement relationship. Three values of soil replacement compaction was studied. Fig. 7 was plotted presenting the relation between the percent compaction of replacement soil and ultimate bearing capacity for the studied replacement soil thickness $(\mathrm{Hc} / \mathrm{b})$.

From the meditation of the results shown on Fig. 7 it is evident that increase of the degree of compacting the replacement soil layer has greatly majored allowable bearing capacity. Also it is clear that whatever the thickness of the replacement soil layer, increasing the percent of soil replacement compaction leads to an increase in ultimate bearing capacity.

From the study of the results shown in Fig. 7 it is evident that the suitable thickness of the upper replacement layer whatever the percent of soil compaction is $\mathrm{Hc} / \mathrm{b}=2.0$.
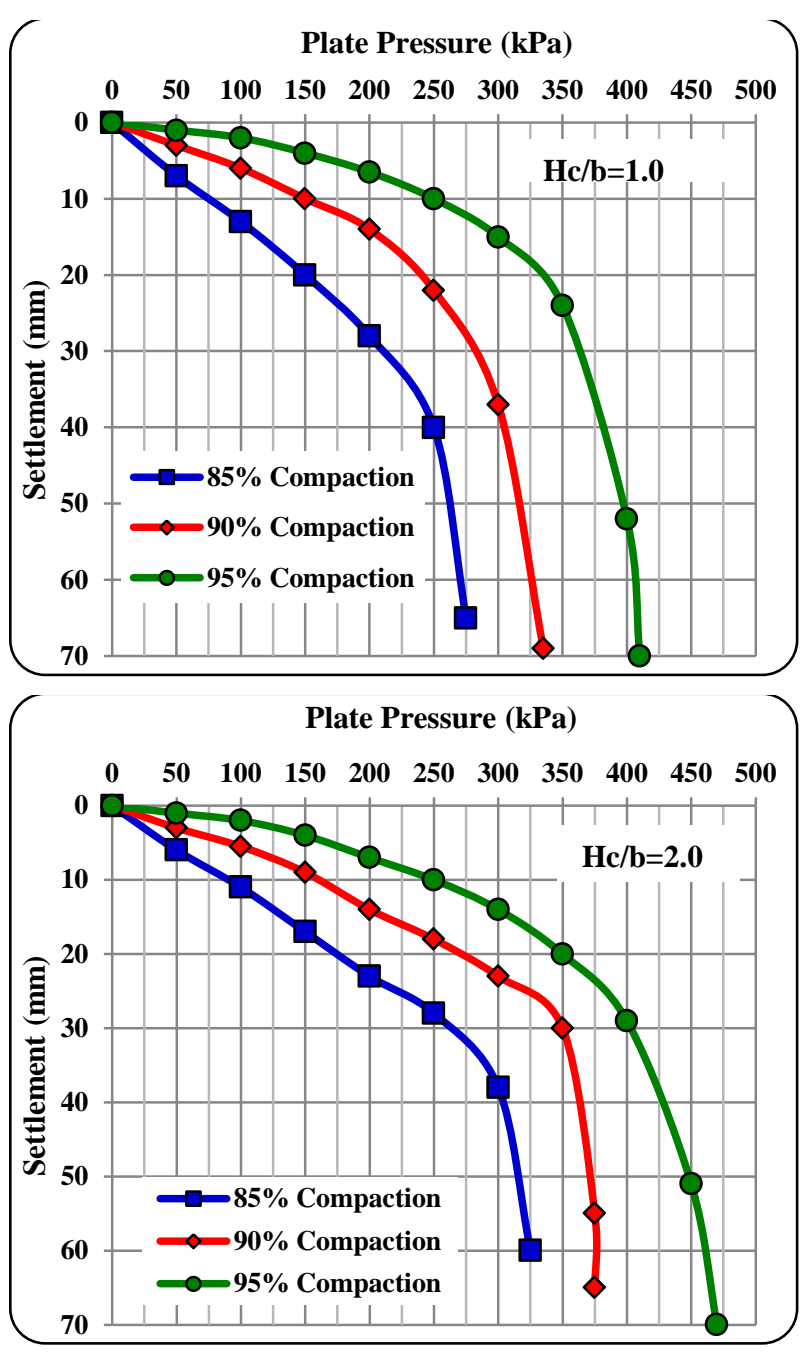

Figure 5. Stress-settlement curves of $75 \mathrm{~cm}$ plate on re-compacted natural soil at various compaction ratios.

As it can be seen from Fig. 7, the percent of compaction of replacement top sand layer have a great effect in increasing the degree of improvement compared with case of footing on collapsing soil without soil replacement.
Compacting the replacement soil make the underneath collapsing layers sustain higher stresses, due to the new load distribution by the strong upper replacement layer.

By comparing the ultimate bearing capacity obtained from the use of $95 \%$ compaction and that from the use of $85 \%$ compaction for the tested footing we find that the enhancement in bearing capacity due to the use of higher percent of compaction (95\%) can not be achieved by increasing thickness of replacement soil, Hc/b by one step. This means that, increasing thickness of soil replacement is more effective than increasing the degree of soil replacement compaction.

This phenomenon can be explained as the increase in soil replacement thickness gave a better redistribution of the stress under the footing and this cause the stress reaching the weak collapsing soil surface is smaller than that when using thin high compacted replacement layer.

An examination of the results shown in fig. 8. elucidated that at the lower degree of compacting soil replacement the associated settlement increases whatever the replacement soil thickness. At higher values of replacement soil compaction, settlement reaches minimum values at $\mathrm{Hc} / \mathrm{b}=1$ then increased by increasing replacement soil thickness. This can be attributed to the increase of volume of soil subjected to loads by increasing cushion thickness below footing.

Fig. 9 was plotted presenting the relation between the percent compaction of replacement soil and ultimate settlement for the studied replacement soil thickness $(\mathrm{Hc} / \mathrm{b})$.

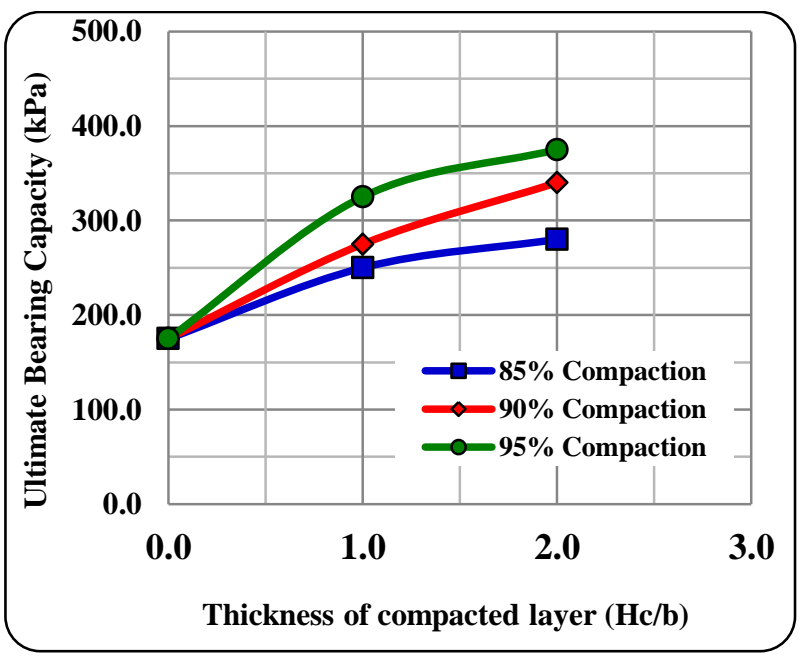

Figure 6. Variation of ultimate bearing capacity with thickness of recompacted layer $\mathrm{Hc} / \mathrm{b}$. 
Proc. of the Seventh International Conference On Advances in Civil and Structural Engineering - CSE 2017.

Copyright (C) Institute of Research Engineers and Doctors. All rights reserved.

ISBN: 978-1-63248-127-6 doi: 10.15224/ 978-1-63248-127-6-33

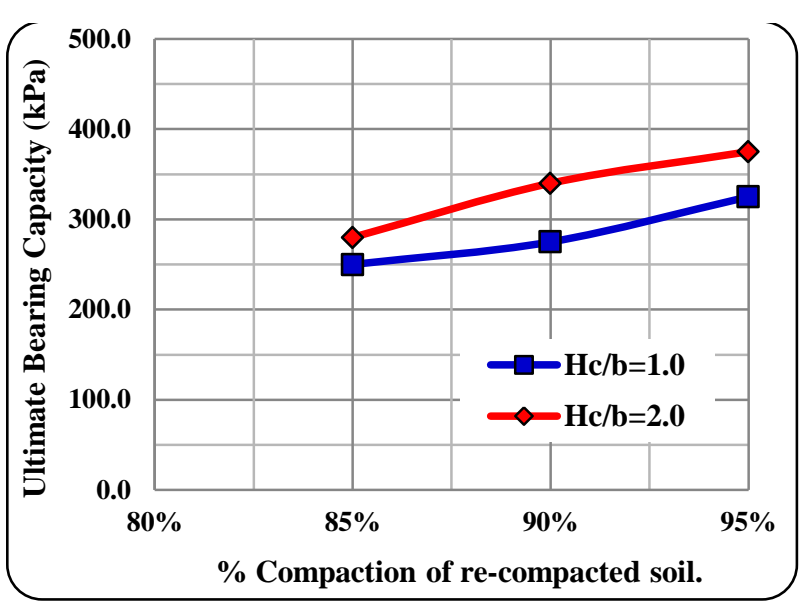

Figure 7. Effect of \% compaction of re-compacted soil on bearing capacity with thickness of re-compacted layer, $\mathrm{Hc} / \mathrm{b}$ ratio.

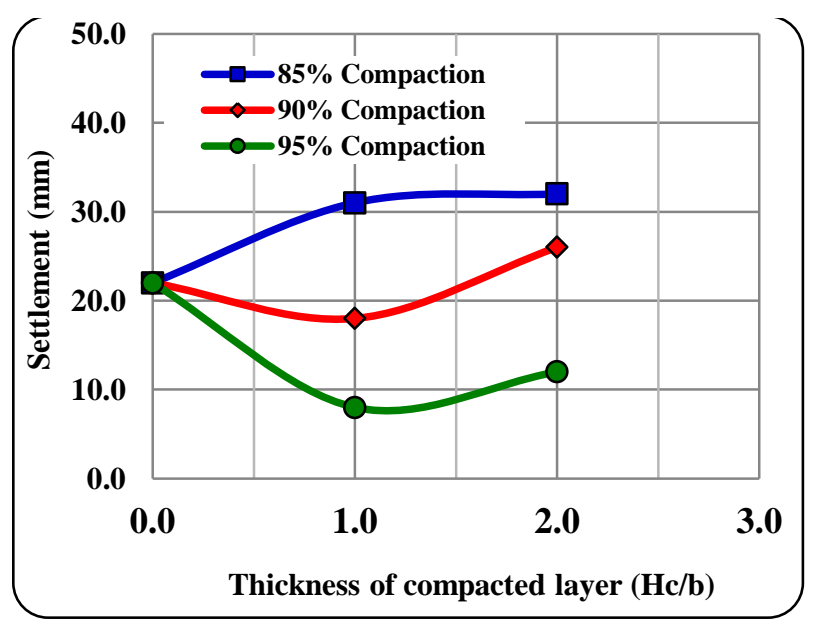

Figure 8. Variation of ultimate settlement with thickness of replacement layer $(\mathrm{Hc} / \mathrm{b})$.

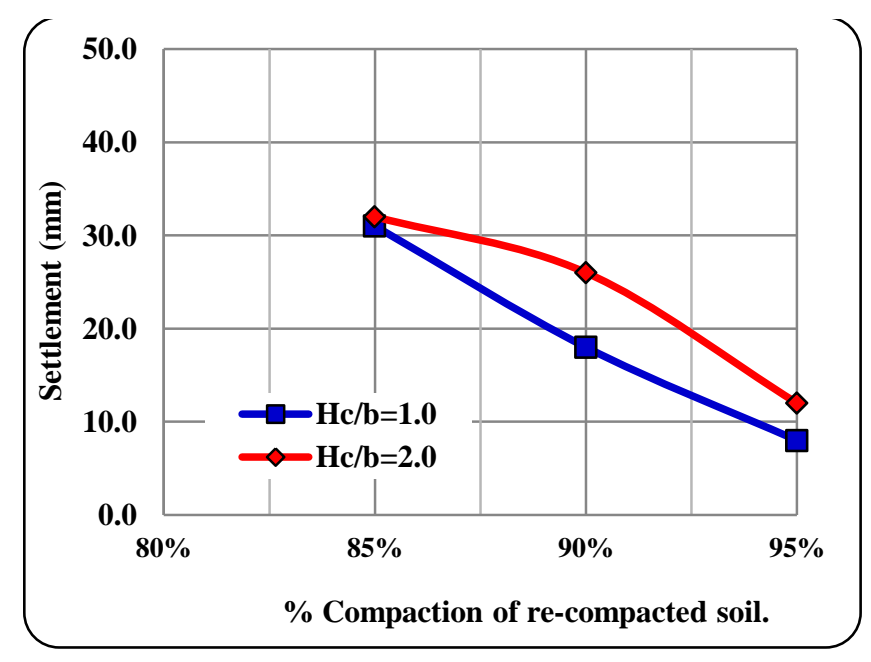

Figure 9. Effect of \% compaction of re-placement soil on settlement.

The outputs shown on this figure elucidated that there is a decrease in the associated settlement with the increase of $\%$ compaction of replacement layer whatever its thickness. This behavior can be attributed to the fact that by increasing $\%$ compaction of replacement layer a new stiff layer was built under the footing.

\section{Conclusions}

The use of re-compaction of natural collapsible soil as a replacement cushion above collapsing soil was investigated using model circular footing in field. Based on the results presented and discussed in this investigation, the following conclusions can be drawn.

- Providing a compacted replacement layer on the top of a relatively collapsing soil layer has proved to markedly increase the bearing capacity obtained from a plate loading test, reducing displacement at failure and changing soil behavior into a noticeable brittle behavior.

- It is revealed that the inclusion of the compacted top layer increases the stiffness of the soil and spreads the applied loads, thereby reducing its intensity on the lower layer.

- The rate of settlement decreases with increase of both thickness and degree of compaction of the replacement layer, and reach maximum decrease at $\mathrm{Hc} / \mathrm{b}=2.0$ and $95 \%$ compaction degree.

- Increasing thickness of compacted replacement layer above collapsible soil is capable of absorbing strain energy prior to failure resulting in an increase in bearing capacity and a decrease in settlement.

- Increasing thickness of soil replacement is more effective than increasing the degree of soil replacement compaction, due to the better distribution of the stresses under the footing causing the stresses reaching the collapsible soil in small values.

- Critical depth of compacted upper layer is 2.0 times footing width, after that increasing depth of compacted layer has small effect on increasing bearing capacity.

- The ultimate stress of the collapsible soil with top recompacted collapsing soil at $95 \%$ compaction increases by $185 \%$ and $214 \%$ respectively as compared to the origin soil, for $\mathrm{Hc} / \mathrm{b}=1$ and $\mathrm{Hc} / \mathrm{b}=2$.

\section{Appendix 1: Notation}

The following symbols are used in this paper

b : Diameter of plate footing model $; \mathrm{cm}$

$\mathrm{Hc}$ : Depth of replacement soil below foundation; $\mathrm{cm}$

$\mathrm{q}_{\mathrm{o}}$ : Bearing capacity of natural clay deposit; KN/m2

$\mathrm{q}_{\mathrm{r}} \quad$ : Bearing capacity for replacement layer; KN/m2

SPT: Standard penetration test.

D : Anchor pile diameter; $\mathrm{cm}$.

L : Anchor pile Length; ms.

\section{References}

[1] Adams, M. and Collin, J. "Large model spread footing load test on geosynthetic reinforced soil foundation," J.of Geotch . Engr., ASCE, 123, No.1, 1997, pp. 66-72.

[2] ASTM, 1997. "Standard test method for nonrepetitive static plate load tests of soils and flexible pavement components, for use in evaluation and design of airport and highway pavements, ",1997,pp. $112-113$.

[3] Ayadat, T. and Hanna, A. M. "Design of Foundations Built on a Shallow Depth (Less than $4 \mathrm{~m}$ ) of Egyptian Macro-Porous Collapsible Soils," Open Journal of Geology, 2013, 3, 209-215 doi:10.4236/ojg.2013.33024. 
[4] Barden, L., McGrown, A., and Collins, K, "The collapse mechanics in partly saturated soil, " Engineering Geology (Amsterdam), 7,1973, pp. $49-60$.

[5] Dudley, J.H. "Review of collapsing soils, " ASCE Journal of the soil Mechanics and Foundation Division, 96(SM3) ,1970, pp. 925-947.

[6] Kakoli, S.T.N., and Hanna, A.M. "Causes of Foundation Failure and Sudden Volume Reduction of Collapsible soil During Inundation," 4th Annual Paper Meet and 1st civil Eng. Congress, December 22-24, 2011. Dhaka, Bangladesh.

[7] Larinov, A.K., "Structural characteristics of loess soils for evaluating their con-structural properties, " Proceed. 6th Inter. Conf. on Soil Mechanics and Foundation Engrg, Rio de Janeiro, 1965, pp. 619-622.

[8] Leonards G. A. (1962). "Foundation engineering, " McGraw-Hill Ed.

[9] Rollins K.M., and Rogers, G.W., " Mitigation measures for small structures on collapsible alluvial soils, " J.Geotech. Engrg., 120(9) ,1994, pp. 153-155.

[10] Sun, P.P., Zhang, M.S. and Zhu, L.F. "Typical Case study of Loess Collapse and Discussion on related Problems," Geological Bulletin of China, 2013, 32(6) : 847-851.

About Author (s):

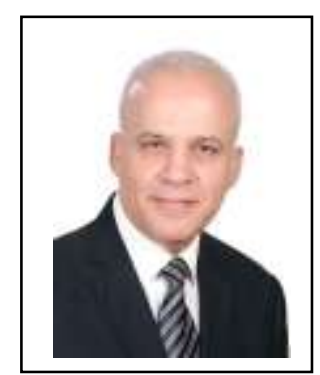

*Vice Dean Faculty of Petroleum and Mining Engineering, Suez University, EGYPT.

*AREA OF INTEREST:

- Soil Mechanics.

- Soil Structure Interaction.

- Improvement of soil and rock properties

- Landslides and Slope stability.

*Membership in professional

Societies

1- Civil Engineers Society.

2- Egyptian Society for Earthquake engineers. 